\title{
Vállalkozói hálózatok határok nélkül
}

\section{Entrepreneurial networks without borders}

\author{
JÓNA GYÖRGY
}

JóNA György: adjunktus, Debreceni Egyetem, Alkalmazott Társadalomtudományi Tanszék; 4400 Nyíregyháza, Sóstói u. 2-4.; jona.gyorgy@foh.unideb.hu; https:// orcid.org/0000-0001-5187-2827

KULCSSZAVAK: interregionális koopetitív hálózatok; kerékagy és küllő hálózati struktúra; bizalom; térhálózati elemzés

ABSZTRAKT: Ebben a tanulmányban magyar, erdélyi, osztrák, lengyel és ukrán régió- és országhatárt átívelő koopetitív hálózatok területi jellemzőit, struktúráit és hatásait mutatom be. A koopetíció egy dinamikus, újszerü vállalatközi kapcsolatrendszer, melyben riválisok egyszerre versenyeznek és kooperálnak egymással. A tanulmány kiindulópontja szerint minden gazdasági hálózatnak van földrajzi kiterjedése, területi struktúrája, ezért a koopetitív hálózatok múködése és hatásmechanizmusai területi aspektusból is vizsgálhatók. A hálózati modellben a csúcspontok a vállalkozások telephelyeit, az összekötő élek a vállalkozások közötti kapcsolatokat jelölik. A vizsgált hálózatokban a versenytársak együttműködnek a közös árubeszerzésben és -szállításban, ezért alacsonyabb egységáron vásárolhatják meg termékeiket. Az így realizált megtakarítást munkahelyteremtésre és jövedelemnövekedésre fordítják. Ebben a cikkben öt informálisan múködő koopetitív hálózat területi sajátosságait mutatom be primer hálózati adatbázisok feldolgozásával. Az adatfelvétel során a hálózatok minden egyes szereplőjével (összesen 370 vállalkozóval) félig strukturált interjút készítettem, valamint kérdőíveket is kitöltettem velük. A primer hálózati adatbázis kvalitatív részét tartalomelemzéssel és longitudinális input-output szekvenciaelemzéssel, kvantitatív részét térhálózati elemzéssel és térökonometriai eljárásokkal dolgoztam fel. Az eredmények szerint a koopetitív hálózatok jelentős mértékben hozzájárulnak a lokális gazdasági fejlődés és növekedés dinamikájához, hiszen 257 új munkahely létrehozását, valamint infláción felüli jövedelemnövekedést (évente átlagosan 4-6\%) lehetett finanszírozni a koopetitív megtakarításokból. Ugyanakkor a vizsgált koopetitív hálózatokban alacsony szintű bizalom mérhető. Mindegyik hálózat kerékagy és küllő struktúrájú, vagyis az integratív funkciót betöltő személyhez kapcsolódnak a szereplők, a cégek közötti közvetlen kapcsolat rendkívül ritka.

György JÓNA: assistant professor, Department of Social Science, University of Debrecen; Sóstói u. 2-4., H-4400 Nyíregyháza, Hungary; jona.gyorgy@foh.unideb.hu; https://orcid.org/0000-0001$5187-2827$

KEYWORDS: transboundary coopetitive networks; hub-and-spoke network topology; trust; spatial network analysis

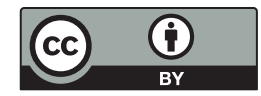


ABSTRACT: The notion of coopetition describes a dynamic interplay of rival companies which both collaborate and compete to increase profitability. All enterprises engaged in coopetition form a network in which the nodes refer to the locations of firms while the edges signify coopetitive interactions. This paper examines spatial characteristics, architectures and economic effects of five transboundary coopetitive networks. They are located in Hungary, Transylvania, Austria, the Ukraine and Poland and comprise 370 competitors.

In the five networks analysed, competitors cooperate in joint transport and purchasing to realise savings that translate into growth of income and/or creation of new jobs. Qualitative and quantitative methods were combined to adequately understand regional network features. For this purpose, a total of 370 semi-structured interviews were conducted and questionnaires completed.

To identify the spatial characteristics of networks, primary graph datasets were produced by integrating advanced toolkits of spatial network analysis and spatial econometrics. Empirical results indicate that coopetitive networks at regional level could exploit economies of scale. They contributed significantly to the dynamics of local economic growth. More precisely, 257 new jobs were created and incomes were increased higher than the inflation rate.

The networks show a hub-and-spoke topology. In every network, all competitors link to a 'focal' node while only some nodes have more than one connection. The dominant firm (hub) is the integrator which is linked to every enterprise, but the direct relationship between the companies is rarely measurable.

\section{Koopetíció a gyakorlatban}

A vállalatok területi kooperációjának számos formája ismert. A stratégiai szövetségek, az ellátási láncok, a regionális klaszterek, a lokális hálózatok, az iparági körzetek régóta a regionális kutatások figyelmének homlokterében állnak (Jackson 2008; Lengyel 2010; Osarenkhoe 2010). Napjainkban azonban a gazdasági hálózatok újszerü típusa formálódik, amelyet koopetíciónak (coopetition) nevezünk (1. ábra). A koopetíció szót a kooperáció (cooperation) és a verseny (competition) kifejezések összekapcsolásával vezette be a társadalomtudományokba Bradenburger és Nalebuff (1996). A koopetíció dinamikus vállalatközi kapcsolatrendszer, melyben rivális cégek egyszerre kooperálnak és versenyeznek egymással profitrátájuk növeléséért (Bengtsson, Kock 1999; Gnyawali et al. 2016; Pathak, Wu, Johnston 2014; Ritala 2012). Emellett más célokat is kitűzhetnek, például az együttmüködéssel csökkenthetik befektetéseik költségeit a technológiai fejlesztés érdekében, mérsékelhetik az új piacokra való belépés akadályait és kiadásait, bizonyos kockázatokat megoszthatnak egymás között, valamint csökkenthetik a termékfejlesztéssel járó időt (Petter et al. 2014).

A 2008-as hitelválság után egyértelmű lett, hogy a versenyelőnyöket kombinálni kell a kollaboratív előnyökkel a felzárkózás és konjunktúra megalapozásáért. Konkrétabban: a vállalatok közötti verseny, a piac láthatatlan keze meghatározza a regionális gazdasági fejlődést, azonban a vállalatközi együttmüködésnek is kulcsfontosságú szerepe van a növekedésben. A verseny és a kooperáció összehangolása lendületet adhat a válság utáni időszakban a térségek komplex fejlődésének. Ennek kiváló példája a koopetíció (Bengtsson, Kock 1999; Gnyawali et al. 2016; Luo 2007; Ritala 2012). 
1. ábra: Gazdasági hálózatok típusai és altípusai

Types and sub-types of economic networks

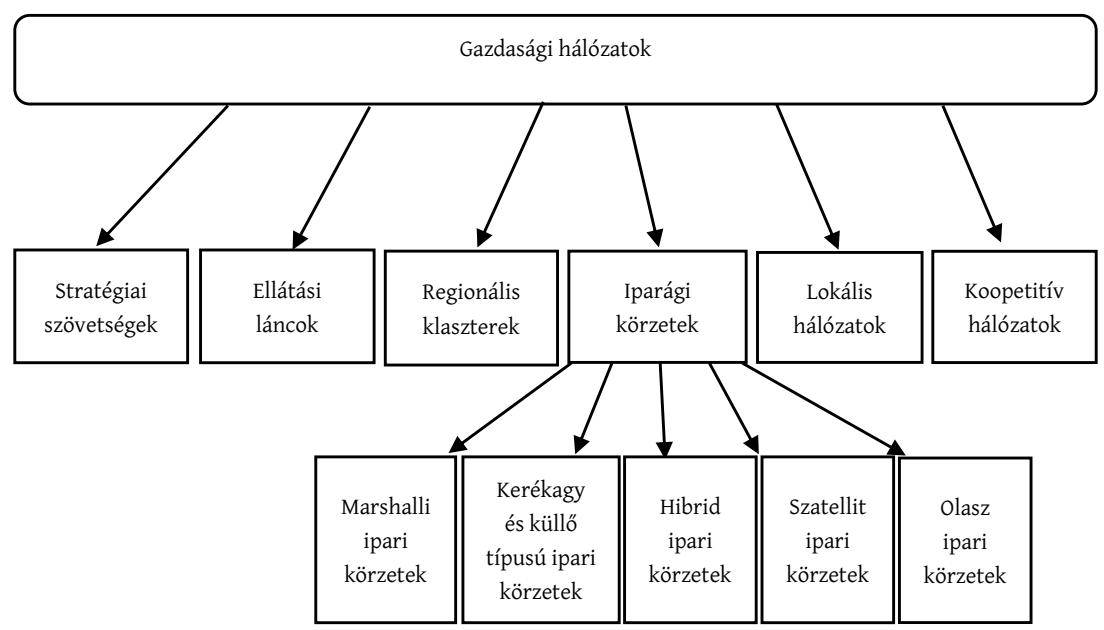

Forrás: saját szerkesztés Dagnino 2009; Lengyel 2010 alapján.

Napjainkban nemcsak a komplementer viszonyban álló cégek között, hanem a konkurensek között is megvalósul együttműködés. Ez természetesen nem jelenti azt, hogy az üzleti élet minden szegmensében együttmüködnek a versenytársak, csupán bizonyos részterületeken kooperálnak. A koopetíció alanya lehet a mikrovállalkozástól a multinacionális vállalatig bármilyen méretű és bármely ágazatban müködő cég, ezekre számos példát találunk az üzleti gyakorlatban. Dubois (2015) hangsúlyozza, hogy a konkurensek a centrum-, félperiferikus és periferikus régiókban, a régiók fejlettségétől függetlenül együttmüködhetnek.

A koopetíció a valóságban egyre gyakoribb vállalatközi együttmüködés. Több esettanulmány bizonyítja a két szereplő közötti koopetíciót, melyben versengő multi- vagy transznacionális vállalatok kooperálnak (Baretta 2008; Ngowi, Pienaar 2005; Osarenkhoe 2010). Ám háromszereplős koopetíció is elöfordul, melyben három rivalizáló céget köt össze koopetitív él (Dagnino 2009). Két vagy három szereplő koopetíciója szinte kivétel nélkül transznacionális vállalatok között jön létre. A nagyobb elemszámú hálózatok rendszerint kis- és közepes vállalkozásokból állnak, például közel 1900 mezőgazdasági vállalkozó koopetitív hálózata az Egyesült Államokban (Lyson, Stevenson, Welsh 2008).

Koopetitív üzleti stratégiára épül több régióban az ipari szektor, többek között a fémipar (Gnyawali, He, Madhavan 2006), a félvezetőgyártás (Pathak, $\mathrm{Wu}$, Johnston 2014), a gyógyszeripar (Quintana-García, Benavides-Velasco 2004), az autógyártás. A lengyel áramszolgáltatás is koopetitív elven müködik - sikeresen (Czakon, Rogalski 2014). A koopetitíció megjelenik számos mezőgazdasági (Choi, Garcia, Friedrich 2010; Schulze-Ehlers et al. 2014), pénzügyi, 
szolgáltató (például egészségügyi - Baretta 2008) szektorban, medium- és hightech vállalatokban (Ritala, Golnam, Wegmann 2014).

A koopetíció gyakoriságában egyértelmű a skandináv régiók fölénye. Bármilyen méretű és korú vállalkozás együttműködési hajlandósága messze a legmagasabb a svéd, a finn, a dán és a norvég térségekben (Breznitz 2009; Rusko 2011). Majdnem hasonló sikereket könyvelhetnek el ausztrál és új-zélandi versenytársak hálózatai is. Az ausztrál bortermelők közel kétharmada koopetitív hálózatban dolgozik (Choi, Garcia, Friedrich 2010), itt leginkább az új borok piaci bevezetésének marketingköltségeit finanszírozzák közösen. Új-Zélandon konkurens mezőgazdasági cégek együtt bíztak meg egy szervezőt piac létrehozására és működtetésére, ahol termékeiket a fizetőképes kereslettel rendelkező fogyasztóknak kínálják (Lawson et al. 2008).

A koopetícióban részt vevő vállalatok hálózatként müködnek, hiszen partnerségi viszony, formális vagy informális együttműködés köti őket össze. A továbbiakban a rivalizáló vállalatok együttműködő halmazát koopetitív hálózatnak nevezem. A koopetitív hálózatban a csomópontok a vállalatok telephelyét jelölik, az összekötő élek pedig a köztük lévő koopetitív kapcsolatokat írják le.

A koopetitív hálózatoknak (ahogyan a gazdasági hálózatok minden típusának) földrajzi kiterjedésük és struktúrájuk is van. Így a térhálózati elemzés módszereivel vizsgálhatók a koopetitív hálózatok regionális sajátosságai (Barthélemy 2011; D’Alessandro, Léautier 2016a, 2016b; O'Sullivan 2014). A koopetícióval foglalkoztak szociológiai, menedzsmenttudományi, játékelméleti és szervezetpszichológiai aspektusból is, ám területi jellemzőit és regionális hatásait kevesen elemezték (Corrado, Fingleton 2012; D’Alessandro, Léautier 2016a, 2016b; Jóna 2016, 2017a, 2017b; Kerr 2017; Mariani 2016; Petter et al. 2014). Ez a tanulmány ezt a hiányosságot próbálja pótolni empirikus adatok felhasználásával.

A gazdasági hálózatok területi jellemzőinek vizsgálatánál fontos megkülönböztetni a földi hálózat, a nem földi hálózat és a területi hálózat fogalmait. A földi hálózat összekötő élei és csomópontjai fizikailag realizálódnak a térben és nem metszik egymást. Ha hidakon, csatornákon, felüljárókon kereszteződnek az élek vagy ha az élek végcéljai azonos pontban találkoznak, akkor is földi hálózatról beszélünk. A valóságban leggyakrabban az infrastrukturális és szállítási hálózatok definiálhatók földi hálózatként. A nem földi hálózat összekötő élei és csúcspontjai fizikailag megtalálhatók a térben és keresztezhetik is egymást (O’Sullivan 2014). A területi hálózatok abban különböznek a földi és nem földi hálózatoktól, hogy a területi hálózatokban a csomópontok földrajzi helye pontosan meghatározható, azonban az összekötő élek nem térbeli kapcsolatok, melyek vertikálisan és horizontálisan is keresztezhetik egymást. Például a gazdasági hálózatokban egy csomópont egy cég földrajzi helyét, az összekötő él pedig a csomópontok közti kapcsolatrendszert, a kommunikációs csatornát jelöli (amely nem a fizikai térben található). A kör tovább bővíthető, hiszen a társadalmi hálózatok (Facebook, Instagram stb.) is definiálhatók területi hálózatként: a csomópontok a hálózathoz tartozó egyén földrajzi helyzetét (például 
lakhelyét) jelentik, az élek pedig a személyes kapcsolatokat (Barthélemy 2011; Scherngell 2013).

A továbbiakban öt ország- és régióhatárt átívelő koopetitív hálózat területi és regionális gazdaságtani sajátosságait mutatom be. Részletesen foglalkozom a koopetitív hálózatok működésével és azzal, hogy miként hatnak e hálózatok az interregionális gazdasági fejlődésre és növekedésre.

\section{A hálózati modell és az alkalmazott módszer}

Egy koopetitív hálózat (network: $N$ ) a vállalkozások telephelyét jelölő csomópontokból (vertices: $V$ ) és a köztük lévő koopetitív élekből (edges: $E$ ) áll. A csúcspontok közötti élek szomszédsági mátrixszal írhatók le. A szomszédsági mátrixban $V_{i j}$ értéke 1, ha létezik közöttük összekötő él, egyébként $V_{i j}$ értéke 0. A hálózati modellben mindegyik él irányítatlan, vagyis a koopetitív kapcsolatot szimmetrikusnak feltételezzük; a hálózatok szomszédsági mátrixa is szimmetrikus. A hálózatok súlyozatlanok, vagyis a modell feltételezi, hogy a kapcsolatok áteresztőképessége, súlya és erőssége azonos. Többszörös élek és hurokélek egyik hálózatban sem találhatók.

Az alábbi öt interregionális koopetitív hálózatot vizsgálom empirikusan:

1. Záhony-Beregszász-Munkács-hálózat ( $V=69$, étteremtulajdonosok hálózata);

2. Nyíregyháza-Kisvárda-Nagyvárad-hálózat (V=99, étteremtulajdonosok hálózata);

3. Budapest-Bécs-hálózat (V=59, designerek hálózata);

4. Katowice-Krakkó-hálózat (V=69, pékségek hálózata);

5. Poznań-Varsó-hálózat ( $V=74$, pékségek hálózata).

Összesen tehát 370 versenytárs került az öt hálózati modellbe. Az öt hálózat diszjunkt halmaz, így egyenként elemezhető és összehasonlítható (Jackson 2008).

Az öt koopetitív hálózatot egy korábbi hazai empirikus kutatás informális kapcsolatrendszeréből sikerült megismernem és feltérképeznem hólabdamódszerrel (Jóna 2016). Korábban megkérdeztem más koopetitív hálózatban részt vevő vállalkozókat, hogy ismernek-e hasonló hálózatot, így jutottam el az öt régió- és országhatárokon átívelő hálózathoz.

Az adatfelvétel során a kvantitatív és a kvalitatív eljárásokat ötvöztem. A 370 magyar, osztrák, lengyel, ukrán és erdélyi vállalkozóval félig strukturált interjút készítettem, valamint kérdőívet is kitöltettem velük. Összesen 370 kérdöív és 370 interjú feldolgozását végeztem el. A két módszer kombinálására azért volt szükség, mert így a hálózati struktúra, a hálózati viselkedés és a hálózati teljesítmény pontosabban megismerhető, empirikusan mérhető (Gnyawali, He, Madhavan 2006). 
Mivel interregionális koopetitív hálózatok területi sajátosságait elemzem, ezért a kvantitatív adatokra a térhálózati és térökonometriai elemzések eszköztárát alkalmazom (Barthélemy 2011; Brinkhoff, Kresse 2012), a kvalitatív adatokat tartalomelemzéssel és longitudinális input-output szekvenciaelemzéssel dolgozom fel.

A hálózatot leíró mutatók (1. táblázat) közül a csomópontok foka ( $k$ ) megmutatja, hány kapcsolattal rendelkezik adott csúcspont. A hálózatok komplexitása számos mutatóval vizsgálható, a modellben ezt elsőként a csomópontok átlagos fokával $(<k>)$ mérem. Az összes kapcsolat száma ( $L)$ a fokszámok összegéből kiszámítható. A hálósűrűség (GD) összehasonlítja a hálózat lehetséges és meglévő éleit. Az $\alpha$ szintén a hálózat összetettségét méri, mely egyenes arányban van az élek számával és fordítottan arányos a csomópontok számával. A klaszterezettségi együttható $(C)[0,1]$ a hálózat kapcsolatsűrűségét mutatja be az alapján, hogy a hálózati szereplők szomszédjai milyen sűrűn kapcsolódnak egymáshoz (például a barátom barátja nekem is a barátom).

A koopetitív hálózatokban szignifikáns szerepe van a földrajzi távolságnak (d). A hálózati modellben a távolságot a csomópontok közötti, km-ben mért légvonalbeli távolsággal operacionalizálom. Az átlagos geodetikus távolság (AP) a legrövidebb út hosszát jelenti, amely $i$ és $j$ pontok között a legkevesebb pontot tartalmazó út távolságával $\left(d_{i j}\right)$ mérhető. A hálózat átmérője (D) a pontok közötti legrövidebb utak hálózati szintű átlaga. A hálózati kisvilágság (SW) azt jelenti, hogy a (rész)hálózatok között a távolság csökken, mert beékelődő csúcspont összeköti őket, a hálózati strukturális lyukak eltűnnek. SW matematikai formalizálását először Watts és Strogatz (1998) végezte el.

A csoportszintű hálózati centralitástípusok azt mutatják meg, hogy adott csomópontok mennyire fontosak, illetve melyik csúcspont a hálózat főszereplője. A fontosság sokféleképpen definiálható, ezért a centralitásnak több méröszáma különböztethető meg.

A Freeman-féle (1979) fokcentralitás $\left(C_{D F}\right)[0,1]$ szerint egy csúcspont hálózati értékét annak fokszáma határozza meg: minél több kapcsolattal rendelkezik egy szereplö, annál fontosabb szerepe van a hálózatban. Értéke nulla, ha minden szereplőnek azonos számú kapcsolata van; értéke 1, ha a szereplőknek egymással egyáltalán nincs kapcsolata és az összes csomópont ugyanahhoz a csúcsponthoz kapcsolódik (ekkor csillaggráfról beszélünk).

A csoportszintü, standardizált közöttiségcentralitás $\left(C_{B}\right)[0,1]$ szerint egy csomópont akkor van központi helyen a hálózatban, ha legalább két szereplő között áll, így képes ellenőrizni, irányítani azokat az éleken keresztül (Brinkhoff, Kresse 2012). Ha a közbülső szereplő nem létezne, akkor a csúcspontok között nem lenne összekötő él, a részgráfok nem lennének összekötve. A standardizált közöttiségcentralitás értéke 0 , ha nincs él a pontok között (vagyis elérhetetlenek egymás számára a csúcspontok) és 1 , ha az összes legrövidebb úton rajta van az adott szereplö.

A közelségcentralitás $\left(C_{C}\right)[0,1]$ szerint az a csúcspont a föszereplő a hálózatban, amely könnyen elér más pontokat és nincs szüksége másik csúcspontra 
1. táblázat: Koopetitív hálózatok területi jellemzőinek mérése Measuring spatial attributes of coopetitive networks

\begin{tabular}{|c|c|c|}
\hline Jelölés & Egyenlet & Leírás \\
\hline$k$ & $k=\sum_{j} V_{i j}$ & a csomópontokból kiinduló kapcsolatok száma \\
\hline$<k>$ & $<k>=\frac{1}{V} \sum_{i} V_{i}=2 E / V$ & $\begin{array}{l}\text { a hálózat komplexitását a csomópontok átlagos foka } \\
\text { mutatja meg. }\end{array}$ \\
\hline$\alpha$ & $\alpha=\frac{E}{V}$ & \\
\hline$L$ & $L=\frac{1}{2} \sum_{i=1}^{V}\left\langle V_{i}\right\rangle$ & \\
\hline GD & $G D=\frac{E}{V(V-1)}$ & a hálózat sűrűségmutatója \\
\hline C & $\begin{array}{c}C=\frac{1}{V} \sum_{i=1}^{V} C_{i} \\
\text { ahol } C_{i}=\frac{2 L_{i}}{\left\langle k_{i}\right\rangle\left\langle\left(\left\langle k_{i}\right\rangle-1\right)\right.}\end{array}$ & $\begin{array}{l}C \text { a teljes hálózat klaszterezettségét, } C_{i} \text { pedig az i-edik } \\
\text { pont klaszterezettségét mutatja. }\end{array}$ \\
\hline$A P$ & $\mathrm{AP}=\frac{\sum_{i=1}^{V} \sum_{j=1}^{V} d_{i j}}{n(n-1)}$ & ahol $d_{i j}$ a pontok közötti legrövidebb távolságot jelöli. \\
\hline SW & $S W=\frac{C}{A P}$ & $\begin{array}{l}\text { SW egyenesen arányos a teljes klaszterezettséggel és } \\
\text { fordítottan arányos a geodetikus távolsággal. }\end{array}$ \\
\hline D & $D=\frac{1}{V(V-1)} \sum_{i \neq j} d_{i j}$ & ahol $d_{i j}$ az i és j csúcsok közötti távolságot jelentik. \\
\hline$C_{S}$ & $C_{S}=\frac{\sum_{\substack{j=1 \\
j \neq i}}^{V} \frac{1}{d V_{i j}} * \frac{d V_{i j}}{d g_{i j}}}{\sum_{\substack{j=1 \\
i \neq j}} \frac{1}{d V_{i j}}}$ & $\begin{array}{l}\text { ahol } d V_{i j} \text { az i és j vállalkozók közötti hálózati távolság, a } \\
d g_{i j} \text { az i és j vállalkozó közötti földrajzi, légvonalbeli } \\
\text { távolság. }\end{array}$ \\
\hline$C_{D F}$ & $\begin{array}{c}C_{D F}=\frac{\sum_{i=1}^{V}\left[C_{D}\left(k^{*}\right)-C_{D}-\left(k_{i}\right)\right]}{[(V-1)(V-2)]}, \text { ahol } \\
C_{D}\left(k_{i}\right)=d\left(k_{i}\right)=\sum_{j} x_{i, j}\end{array}$ & $\begin{array}{l}\text { ahol } C_{D F} \text { a csoportszintü Freeman-féle fokcentralitás, } \\
d\left(k_{i}\right) \text { az } i \text { szereplő foka, } C_{D}\left(k^{*}\right) \text { pedig a legmagasabb fok. }\end{array}$ \\
\hline$C_{B}$ & $C_{B}(i)=\sum_{i \neq j} \frac{V_{i j}(E) / V_{i j}}{(V-1)(V-2) / 2}$ & $\begin{array}{l}\text { ahol } V_{i j} \text { az } i \text {-ből j-be futó legrövidebb utak száma, } V_{i j}(E) \\
\text { pedig az } i \text {-ből } j \text {-be futó legrövidebb utak közül azok, } \\
\text { melyek } E \text { ponton keresztül haladnak. }\end{array}$ \\
\hline$C_{C}$ & $C_{C}\left(V_{i}\right)=\left(\sum_{i=1}^{V} d g_{i j}\right)^{-1}$ & \\
\hline
\end{tabular}

Forrás: Barabási 2016; Barthélemy 2011; Corrado, Fingleton 2012; Haggett, Chorley 1969; Holl, Mariotti 2017; O’Sullivan 2014; Watts, Strogatz 1998 alapján.

ahhoz, hogy mást elérjen. A közelségcentralitás tehát megmutatja, hogy egy csúcspont milyen könnyen tud kapcsolatot teremteni egy csomóponttal.

Viszonylag ritkábban alkalmazzák az egyenességcentralitást $\left(C_{S}\right)$. Ez abból indul ki, hogy a földrajzilag közelebb lévő pontok fontosabbak, mint a távolabb lévők, ezért a kisebb távolságoknak nagyobb jelentőséget kell tulajdonítani a 
mérések során (Jackson 2008). A vizsgálatban kizárólag csoportszintű alapmutatókat alkalmazok, melyekkel a koopetitív hálózatok általános földrajzi jellemvonásai és szerkezete írhatók le.

\section{A határokon átívelő koopetitív hálózatok általános jellemzői}

A vizsgált gazdasági hálózatok több közös vonással rendelkeznek. Mind az öt hálózat átível ország- és regionális határokon. Mindegyikük informális alapon szerveződik és működik, a szereplők között nincs hivatalos együttműködési szerződés. A riválisok megértették, hogy racionális döntés adott hálózatba bekapcsolódni a profitráta emelése érdekében; a gazdasági szükségszerűség felülírja a köztük lévő személyes ellentéteket. Mindegyik hálózat a 2008-as hitelválság után jött létre. Ez azzal magyarázható, hogy a válság forráshiányt okozott, a vállalkozások mutatói hónapról hónapra romlottak, ezért új megoldásokat kellett találniuk a deficit korrigálására. Anyagi forrás hiányában a vállalkozók kapcsolati tőkéjüket gazdasági tőkévé konvertálták (hálózatosodtak), ami azóta is jelentősen meghatározza piaci pozíciójukat (Bourdieu 2004). Az összes hálózati szereplő mikro-, kis- vagy középvállalkozóból áll.

A céghálózati térképek (2-6. ábra) az öt koopetitív hálózat földrajzi kiterjedését mutatják be. A Nyíregyháza-Kisvárda-Nagyvárad és a Záhony-Beregszász-Munkács koopetitív hálózatok helyi étteremtulajdonosokból állnak. Előbbi 2010-ben informálisan jött létre, jelenleg 99 (Nyíregyházán 36, Kisvárdán 12 és Nagyváradon 51 vállalkozó) alkotja, míg utóbbi 2011-ben alakult és jelenleg 69 rivális (Záhonyban 9, Beregszászon 39 és Munkácson 21) vállalkozásból áll.

Az öt koopetitív hálózat partnerségi kapcsolatrendszere területileg meghatározott. A 2-6. ábrák bemutatják, hogy riválisok között nincs vagy csak alig mérhető együttműködési hajlandóság. Adott városon belül versenytársak között kialakul koopetitív kapcsolat (vagyis a városon belüli csúcspontokat él köti össze), azonban városok közötti él egyetlen hálózatban sem fedezhető fel. Például a Nyíregyháza-Kisvárda-Nagyvárad-hálózatban Nyíregyházán 36-ból 11, Kisvárdán 12-ből 3, míg Nagyváradon 51-ből 19 rivális kommunikál egymással az integratív szerepet betöltő vállalkozón kívül, akit a nagyméretű nagyváradi pont mutat.

Két lengyel koopetitív hálózatot is feltérképeztem: a Katowice-Krakkóhálózatba 69 pékség (Katowicében 26, Krakkóban 43), a Poznań-Varsó-hálózatba pedig 74 pékség (Poznańban 31, Varsóban 43) integrálódott. A pékségek kizárólag péksütemények értékesítésével foglalkoznak, termeléssel nem. Mindkét lengyel koopetitív hálózat közvetlenül a hitelválság után jött létre, előbbi 2009-ben, utóbbi egy évvel később. A lengyel céghálózatok is regionálisan meghatározottak: Katowicében 26-ból 5, Krakkóban 43-ból csupán 8, míg 
2. ábra: A Nyíregyháza-Kisvárda-Nagyvárad koopetitív hálózat The Nyíregyháza-Kisvárda-Oradea coopetitive network

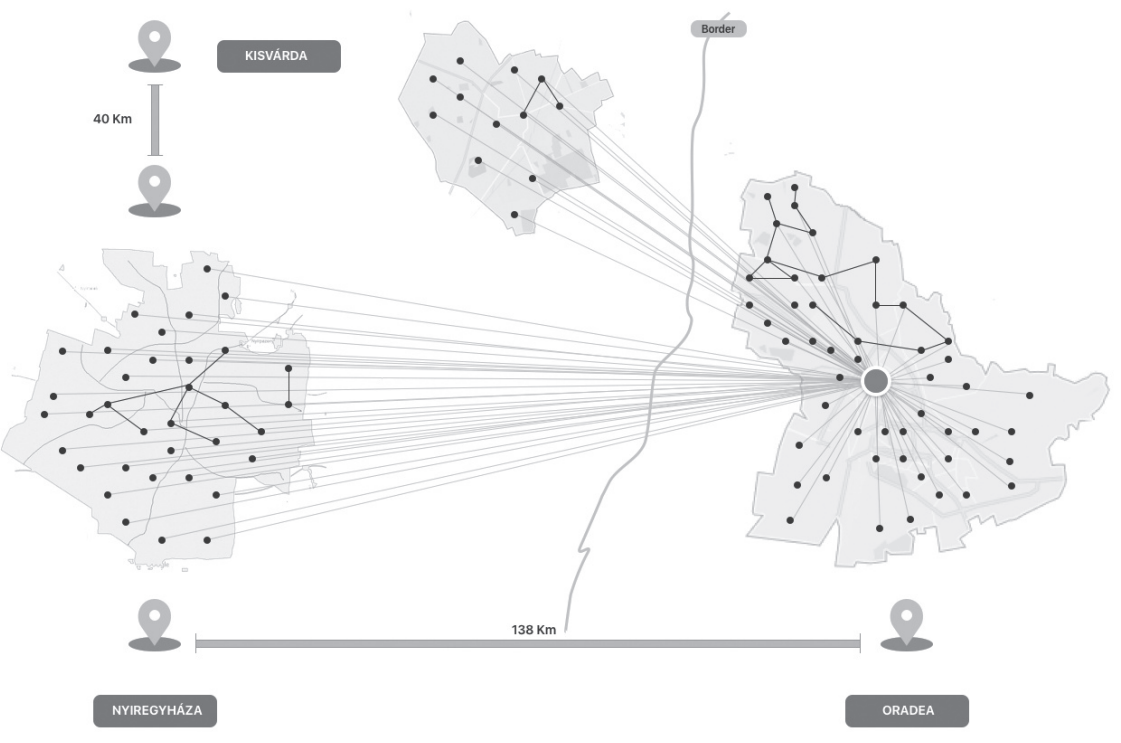

3. ábra: A Záhony-Beregszász-Munkács koopetitív hálózat The Záhony-Berehove-Munkachevo coopetitive network

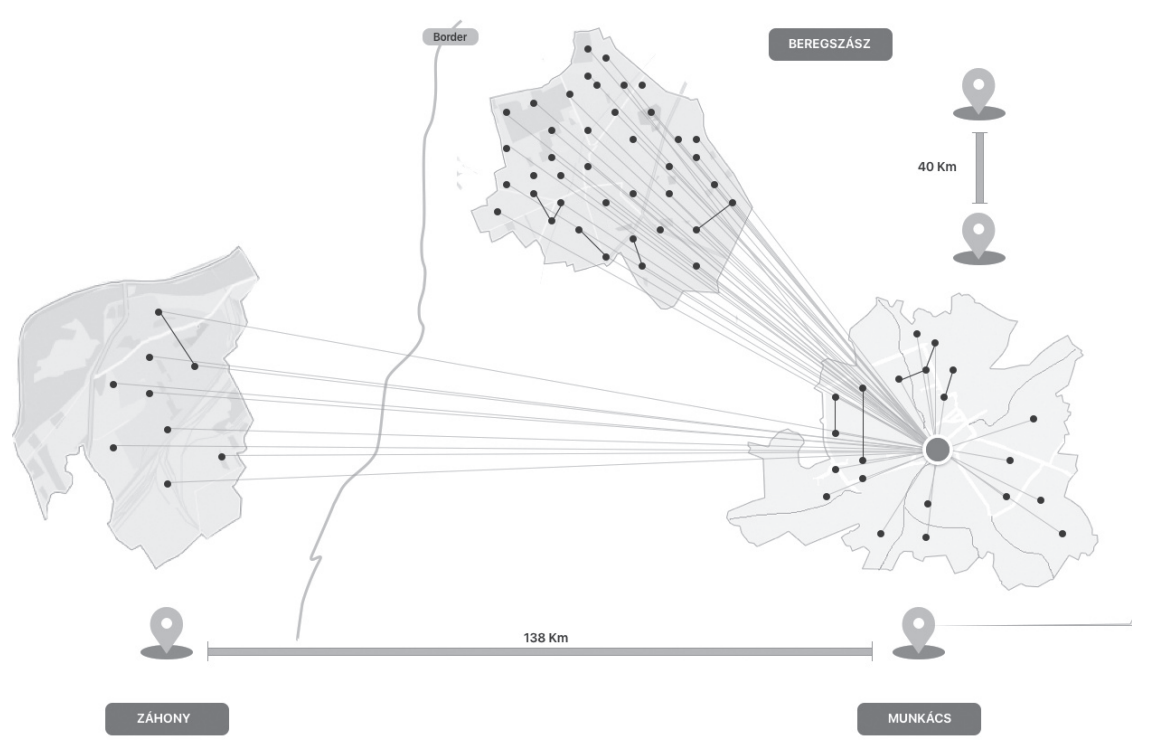


Poznańban 31-ből 14, Varsóban 43-ból 18 versenytárs között jött létre koopetitív kapcsolat, a többiek kizárólag az integratív szerepet betöltő vállalkozón keresztül kommunikálnak.

Végül a 2010-ben létrehozott Budapest-Bécs interregionális koopetitív hálózatba összesen 59 designer csatlakozott. Budapesten 31-ből 6, míg Bécsben 28-ból 13 rivális designer között alakult ki koopetitív kapcsolat, a többiek csupán az integratív szerepet betöltő vállalkozóval tartják a kapcsolatot (6. ábra).

4. ábra: A Katowice-Krakkó koopetitív hálózat

The Katowice-Kraków coopetitive network
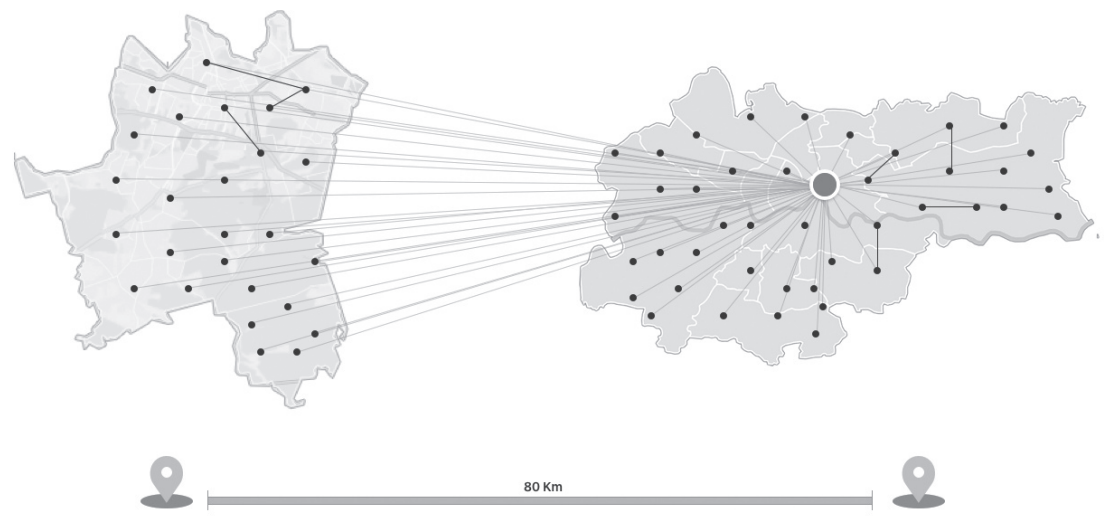

5. ábra: A Poznań-Varsó koopetitív hálózat

The Poznań-Warsaw coopetitive network

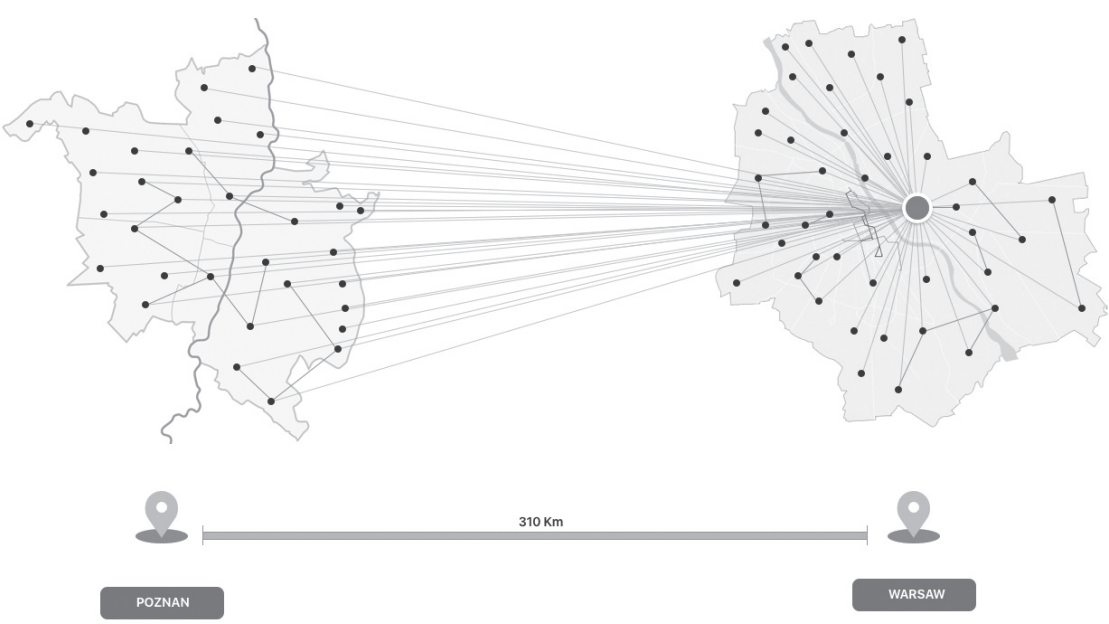


6. ábra: A Budapest-Bécs koopetitív hálózat

The Budapest-Vienna coopetitive network

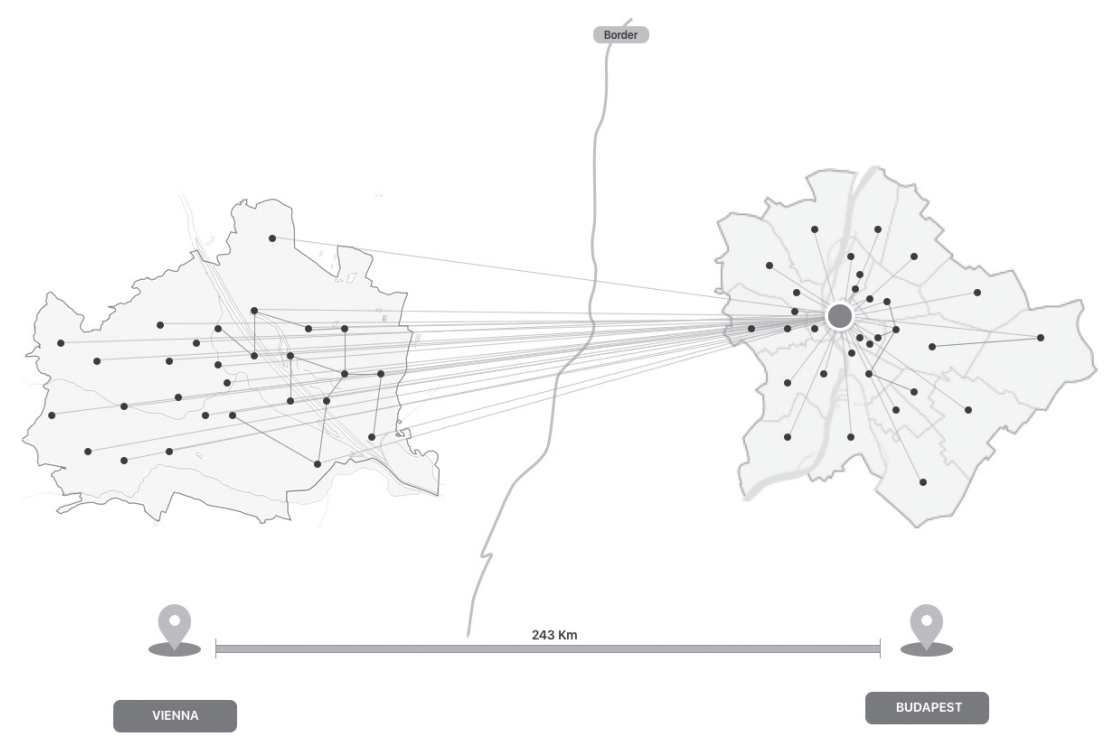

Az integratív szerepet betöltő vállalkozónak főszerep jut a koopetitív hálózatban, ezért részletesebben meg kell vizsgálni szerepét. A versenytársak kooperációja egyetlen térségben sem zökkenőmentes a korábbi kíméletlen gazdasági verseny miatt; a bizalmatlanság szintje kiugróan magas. Ám létezik egy integratív funkciót betöltő személy, akiben mindannyian megbíznak (Vesalainen, Valkokari, Hellström 2017), őket nagyméretű pont jelöli a céghálózati térképeken. Az integratív szerepet betöltő vállalkozó kapcsolatban áll a hálózat összes tagjával, míg a riválisok egymással nagyon ritkán lépnek interakcióba. Koopetitív hálózatokban a kapcsolatsűrűség rendszerint alacsony (az ilyen kapcsolati gráfot ritka hálózatnak nevezzük), csupán akkora, amekkorával a koopetitív hálózat fennmarad. Az empirikus adatok egyértelmüen alátámasztják: a vizsgált koopetitív hálózatokban nincs szükség arra, hogy az összes versenytárs megbízzon egymásban, ez életszerűtlen elvárás volna. A bizalmat az integratív szerepet betöltő vállalkozó teremti meg; a hálózat hatékony működéséhez az is elég, ha csupán benne bíznak meg a hálózat tagjai.

Az empirikus elemzés egyértelműen ellentmond annak a hipotézisnek, mely szerint egy gazdasági hálózat teljesítménye annál magasabb, minél több aktor bízik meg egymásban, illetve kommunikál egymással. A legtöbb korábbi hálózati elemzés azt sugallja, hogy a teljes hálózatok (melyben minden egyes csomópont mindegyik csomóponttal össze van kötve) eredményessége a legjobb (Bachmann, Inkpen 2011; Breuer, McDermott 2012). Az a felfogás, hogy a magasabb bizalmi szint nagyobb hálózati hatékonyságot teremt, a koopetitív 
hálózatok esetében nem helytálló. A riválisok hálózatában leggyakrabban az integratív szerepet betöltő szereplőben bíznak meg a szereplők, rajta keresztül kommunikálnak egymással, a valóságban tehát a legalacsonyabb bizalmi szinten müködik a hálózat - kiválóan.

Az integratív szerepet betöltő vállalkozó közvetít a riválisok között, tervezi és koordinálja a koopetitív cselekményeket. Gyakorlati jelentőségét a következő interjúrészlet jól bemutatja. „Szó sem lehet arról, hogy beszéljek Z. K.-val, az egy gazember (egy rivális, aki szintén tagja a hálózatnak), többször is becsapott, utálom! Azonban X. Y.-t (az integratív szerepet betöltő vállalkozó) ismerem régóta, tudom, hogy benne meg lehet bizni. Ő mindig megkérdezi, hogy kell-e nekem valamilyen árut beszerezni, aztán megszervezi a többi konkurenssel, hogy együtt szállítsuk a szükséges árut. De nemcsak itt Nyíregyházán, hanem Kisvárdán és Nagyváradon is vannak ilyen éttermesek, akikkel kapcsolatban áll - én ki nem állhatom öket... Ez az egész azért jó, mert így olcsóbban megvehetjük a dolgokat a nagykerben, ezzel pénzt spórolunk és még a benzinköltség is kevesebb, mert nem kell mindenkinek egyenként áruért menni... De arról szó sem lehet, hogy Z. K.-val én leálljak beszélni. X. Y. jól kijön vele és egyezkedik, szervezkedik vele, hogy hozzuk közösen az árut." (78. interjú)

Mind az öt koopetitív hálózat szereplői a közös árubeszerzésben és áruszállításban kooperálnak, a többi üzleti tevékenységben (árképzés, eladás, menedzsment, a telephely kiválasztása stb.) egymással versenyben állnak. A koopetícióból származó megtakarításnak tehát két forrása van: egyrészt az áruszállítás költségét csökkentik, illetve megosztják az ezzel kapcsolatos kockázatokat. Másrészt, mivel együtt vásárolják a termékeket, a nagykereskedésben egy vásárlónak számítanak, árkedvezményben részesülnek, így alacsonyabb egységáron vásárolhatnak.

A valóságban a koopetíció úgy valósul meg, hogy az integratív funkciót betöltő személy összegyűjti a szereplőktől azt a piaci információt, hogy kinek pontosan milyen termékre és milyen mennyiségben van szüksége (Holl, Mariotti 2018; Vesalainen, Valkokari, Hellström 2017). Ezután kiszámítja, hogy az árumennyiség elszállítása hány járművet igényel. Az áruszállítást mindig más végzi, az integratív funkciót betöltő személy ügyel arra, hogy „éves szinten mindig, mindenki egyformán sorra kerüljön, az áruszállitásból mindenki egyformán kivegye a részét." (36. interjú). Például a Katowice-Krakkó-hálózatban nem szükséges mind a 69 pékségnek elindulni áruért, elég, ha 45-47 jármű szállítja a 69 vállalkozónak a termékeket. Természetesen az áruszállítás anyagi terhét az összes vállalkozó viseli. Végül az integratív funkciót betöltő szereplő a leadott igények alapján egyeztet és dönt a közös áruszállítás időpontjáról, és erről mindenkit értesít - rendszerint e-mailben. Miután a szükséges árut megvették, bepakolják az árufuvarozó járműbe. Ezután a hálózati szereplők által korábban kijelölt, minden rivális számára viszonylag könnyen megközelíthető helyszínen szétosztják egymás között a megvásárolt árut. 


\section{Az interregionális koopetitív hálózatok struktúrája}

A tanulmány egyik tétele, hogy a hálózati hatások és externáliák területi terjedését, intenzitását a hálózat struktúrája határozza meg. Ezért először a koopetitív hálózatok szerkezetét szükséges megvizsgálni, és csak ezután térhetünk rá a hálózati hatásmechanizmusok elemzésére (Acemoglu, Ozdaglar, Tahbaz-Salehi 2012). A hálózati hatás és a hálózati externáliák fogalmait gyakran összekeverik, azonban a kettő nem felcserélhető. A hálózati hatás azt mutatja meg, hogy a hálózat tagjai mekkora hasznot vagy veszteséget realizálnak a hálózatosodás révén. A hálózati externália azt jelenti, hogy a gazdasági hálózat a hálózaton kívüli aktorokra is hatást gyakorol. A hálózati hatás tehát a hálózaton belüli, a hálózati externália a hálózaton kívüli befolyást méri. Ebben a tanulmányban kizárólag a hálózati hatást mérem.

A mérések eredményei (2. táblázat) azt mutatják, hogy az öt koopetitív hálózat kerékagy-küllő topológiát követ. Ez azt jelenti, hogy egy szuperközéppont található a hálózatban (az integratív funkciót betöltő személy), ő irányítja és ellenőrzi az összes koopetitív eseményt. A hálózatok e középpontja minden egyes csomóponttal össze van kötve, magához vonzza a kapcsolatokat (esetünkben mindet), míg a riválisok között csupán elszórtan található összekötő él.

A 2. táblázatból kiderül, hogy a centralitás bármely típusát választjuk, az integratív szerepet betöltő személy nélkülözhetetlen a hálózatban. Ez a szereplő biztosítja a hálózat magas robusztusságát, a véletlen hálózati támadásokkal szembeni erős védekezőképességet. Viszont az irányított, tudatos és jól célzott hálózati támadásokkal szemben a kerékagy-küllő hálózati architektúra rendkívül sebezhető lenne (D’Alessandro, Léautier 2016a).

2. táblázat: Az öt koopetitív hálózat strukturális jellemzői (2016)

Structural characteristics of five coopetitve networks (2016)

\begin{tabular}{cccccc}
\hline Mutató & $\begin{array}{c}\text { Záhony- } \\
\text { Beregszász- } \\
\text { Munkács }\end{array}$ & $\begin{array}{c}\text { Nyíregyháza- } \\
\text { Kisvárda- } \\
\text { Nagyvárad }\end{array}$ & Budapest-Bécs & Katowice-Krakkó & Poznań-Varsó \\
\hline $\mathrm{V}$ & 69 & 99 & 59 & 69 & 74 \\
$\mathrm{E}$ & 99 & 131 & 77 & 81 & 105 \\
< > & 2,869 & 2,646 & 2,61 & 2,34 & 2,82 \\
$\alpha$ & 1,434 & 1,323 & 1,355 & 1,17 & 1,41 \\
$\mathrm{GD}$ & 0,0147 & 0,013 & 0,022 & 0,017 & 0,019 \\
$\mathrm{C}$ & 0,961 & 0,971 & 0,973 & 0,948 & 0,962 \\
$\mathrm{AP}$ & 1,211 & 1,467 & 2,995 & 2,634 & 3,624 \\
$\mathrm{SW}$ & 0,793 & 0,661 & 0,325 & 0,359 & 0,265 \\
$\mathrm{D}$ & 151 & 148 & 261 & 111 & 324 \\
$\mathrm{C}$ & 0,0066 & 0,0067 & 0,0038 & 0,0090 & 0,0030 \\
$\mathrm{C}_{\mathrm{DF}}$ & 0,918 & 0,961 & 0,943 & 0,930 & 0,923 \\
$\mathrm{C}_{\mathrm{B}}$ & 0,921 & 0,968 & 0,952 & 0,946 & 0,916 \\
$\mathrm{C}_{\mathrm{D}}$ & 0,942 & 0,966 & 0,959 & 0,939 & 0,921 \\
\hline
\end{tabular}


A szuperközéppont lehetőséget biztosít a hálózat perifériáján lévő aktoroknak is, hogy a hálózati tevékenységben a hálózat centrumában lévőkhöz hasonlóan részt vehessenek; a kooperatív élekben futó információ torzítatlanul jut el a hálózat centrumához és perifériájához is.

\section{A régió- és országhatáron átívelő hálózati hatás}

A koopetitív hálózatok hatása (NE) a foglalkoztatottság (E) és a jövedelem (I) változásával mérhető. A kérdés tehát az, hogy a koopetitív megtakarításból (S) hány százalékban finanszírozható a munkahelyteremtés és a jövedelemnövekedés; $\mathrm{NE}=\mathrm{S} /(\mathrm{E}+\mathrm{I})$. Amennyiben $\mathrm{NE} \geq 1$, akkor pozitív hálózati hatásról beszélünk, a jövedelemnövekedés és a foglalkoztatásbővülés finanszírozható a koopetitív megtakarításból. Ha NE < 1, akkor a koopetitív megtakarítás önmagában nem elég a jövedelemnövekedés és a foglalkoztatásbővülés finanszírozásához. Ezzel a számítással mérhetővé válik, hogyan alakul időben a koopetitív hálózati hatás (Jóna 2017a).

A 7. ábrán látható, hogy az NE-értékek viszonylag folyamatosan emelkednek, kivéve a Nyíregyháza-Kisvárda-Nagyvárad-hálózatnál, ahol 2011-ben komoly visszaesés tapasztalható. Ekkor több szereplő is kivált a hálózatból

7. ábra: Hány százalékban fedezi a koopetitív megtakarítás a jövedelemnövekedést és a munkahelyteremtést? (\%)

What proportion of income growth and job-creation do coopetitive savings cover? (\%)

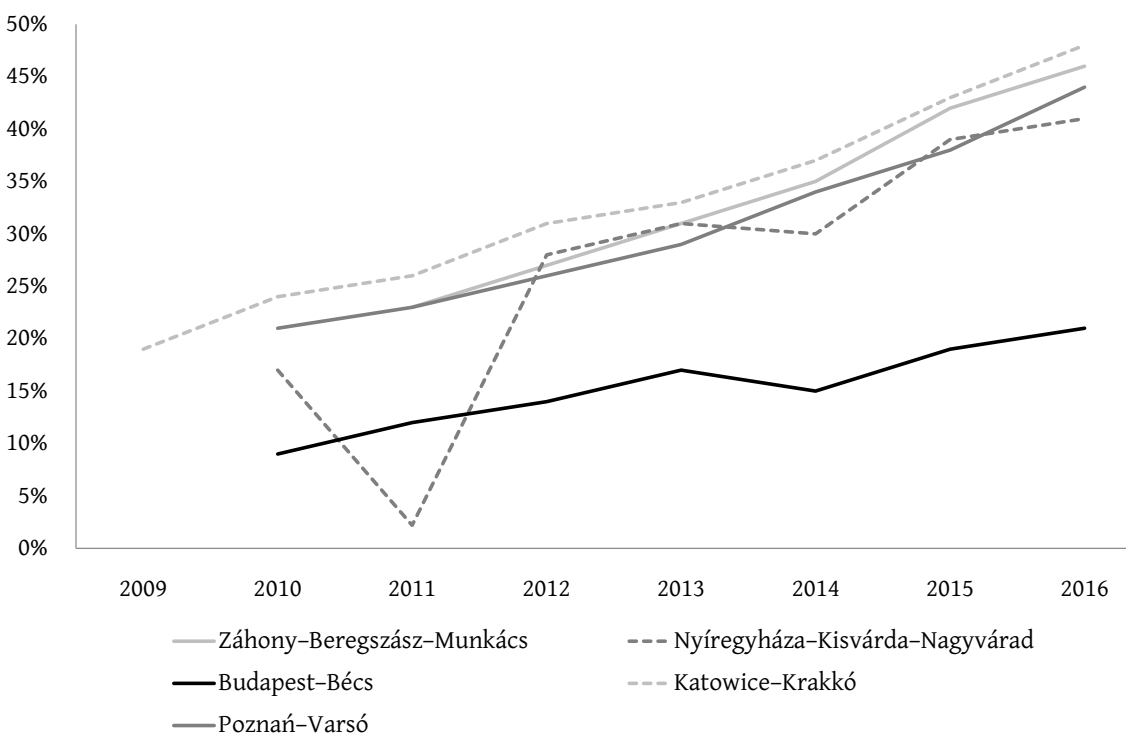


(pletyka terjedt a hálózatban), akiknek helyét újabb vállalkozók vették át. Ugyanakkor leolvasható az is, hogy a koopetitív hálózatok időbeni fejlődésével egyre nagyobb jövedelemnövekedés vált realizálhatóvá és a munkahelyek számát is bővítették. A 3. táblázat alátámasztja, hogy az öt hálózat hétéves (kivéve a Katowice-Krakkó-hálózatot, mely 8 éve létezik) működése alatt összesen 257 új munkahely megteremtéséhez járult hozzá.

Ha a 7. ábrát és a 3. táblázat adatait összevetjük, látható például, hogy a Katowice-Krakkó-hálózatban 2016-ban hat új munkahely jött létre, a kiadás majdnem felét a koopetícióból származó megtakarításokból fedezték. Vegyük észre, hogy a koopetitív megtakarítások közvetlenül a közös árubeszerzés és -szállítás után realizálódnak, az árkedvezmény és az alacsonyabb szállítási költségek haszna azonnal megjelenik a hálózati szereplők gazdasági teljesítményében.

A 7. ábra arra is felhívja a figyelmet, hogy mind az öt hálózat megtakarításokhoz vezet a szereplők számára és a regionális gazdasági fejlődés kiadásai különböző arányban finanszírozhatók belőle. A legtöbb hálózatban lehetséges akkora megtakarítás, amelyből az új munkahelyek teremtésének és a jövedelemnövekedésnek legalább egyharmadát fedezni lehet. Nyilvánvaló, hogy ahol szinte már napi rutinná vált a közös árubeszerzés és -szállítás (lásd a Katowice-Krakkó- és a Záhony-Beregszász-Munkács-hálózatot), ott a $C_{C}$ értékek is magasabbak, mint abban a hálózatban, ahol akár több hét is eltelik két koopetitív tevékenység között (Budapest-Bécs-hálózat). A koopetíció - esetünkben a riválisok közös árubeszerzése és -szállítása - racionális döntésnek nevezhető, mert új anyagi forrást teremt; a koopetitív hálózatok a regionális gazdasági fejlődés és növekedés új tényezőinek nevezhetők (Choi, Garcia, Friedrich 2010; Jóna 2017a, 2017b).

Ezzel szemben több bírálat szerint a koopetíció elhanyagolható mértékben járul csak hozzá a gazdasági fejlődéshez. Ezen érvelések szerint a koopetitív megtakarításokból meglehetősen kevés új munkahelyet és kismértékü jövedelemnövekedést lehet finanszírozni. A koopetíció valóban nem „világmegváltó” koncepció, nem globális, hanem inkább lokális együttmüködésen alapul, egy kisebb földrajzi egység helyi társadalmában hatékony. Azonban érdemes összevetni két adatot: 2018-ban a Rehau-Automotive Kft. 150 millió eurót fektetett be egy újhartyáni cég alapításába, amellyel több, mint 720 új munkahelyet fog létesíteni. Ezzel szemben a fenti öt koopetitív hálózat 257 új munkahelyet hozott

3. táblázat: Az új munkahelyek száma a hálózatokban

Number of new jobs in the networks

\begin{tabular}{lcrrrrrrrr}
\hline \multicolumn{1}{c}{ A hálózat neve } & 2009 & 2010 & 2011 & 2012 & 2013 & 2014 & 2015 & 2016 & Összesen \\
\hline Záhony-Beregszász-Munkács & - & - & 8 & 10 & 5 & 7 & 12 & 11 & 53 \\
Nyíregyháza-Kisvárda-Nagyvárad & - & 13 & 15 & 14 & 21 & 20 & 14 & 13 & 110 \\
Budapest-Bécs & - & 3 & 5 & 2 & 2 & 3 & 3 & 4 & 22 \\
Katowice-Krakkó & 4 & 2 & 4 & 7 & 5 & 7 & 7 & 6 & 42 \\
Poznań-Varsó & - & 4 & 3 & 4 & 6 & 4 & 4 & 5 & 30 \\
\hline
\end{tabular}


létre külső (kormányzati, uniós stb.) támogatás nélkül, kapcsolati tőkéjének gazdasági tőkévé konvertálásával, amellyel megtakarítást realizált. Végső soron a hálózat által lefedett térségek kitettsége csökkent, autonómiájuk javult.

\section{Összefoglalás}

A tanulmány célja volt, hogy hálózati adatbázisok feldolgozásával elemezze öt koopetitív hálózat területi jellemzőit és gazdasági fejlődésre gyakorolt hatását. A kutatás eredményei szerint a lokalizációs előnyök kihasználásában a koopetitív hálózatoknak fontos szerepe van. Nagyon rövid idő alatt megjelentek a koopetícióból származó megtakarítások, melyek közvetlenül hatnak a foglalkoztatási ráta javulására, a jövedelemszint emelkedésére és a helyi társadalom jólétére. A koopetitív megtakarítás jövedelemteremtő beruházás. Ugyanakkor a vállalkozói versenykultúra fejlődését jelzi az integratív funkciót betöltő vállalkozó megjelenése és informális keretek közötti sikeres működése. Többen attól tartottak, hogy a hálózati főszereplő vissza fog élni a birtokába kerülő piaci információkkal, vertikális hálózati struktúrát fog építeni és a hálózat rövid időn belül eltűnik. A gyakorlat azonban nem ezt mutatja: a csúcspontok szinte csak a szuperközponttól kapnak információt, ennek következtében a hálózati interakciós zaj csökken, a kommunikáció letisztul, ennek eredménye, hogy tiszta, érthető adatokat kapnak a konkurens vállalkozók a közös árubeszerzésről és -szállításról. A régió- és országhatárokon átívelő koopetitív hálózatok nyereségesen müködnek évek óta.

A jövőben a regionális politika feladata lehet kidolgozni a gazdasági hálózatokra épülő területi fejlesztéspolitikai koncepciót. Ennek keretében az üzleti hálózati hatások és externáliák terjedését szükséges felerősíteni - akár határokon átívelő szinten is.

\section{Köszönetnyilvánítás}

A tanulmány a Bolyai János Kutatási Ösztöndíj támogatásával készült.

\section{Irodalom}

Acemoglu, D., Carvalho, V. M., Ozdaglar, A., Tahbaz-Salehi, A. (2012): The network origins of aggregate fluctuations. Econometrica, 5., 1977-2006. http://doi.org/f39tth

Bachmann, R., Inkpen, A. C. (2011): Understanding institutional-based trust building processes in inter-organizational relationships. Organization Studies, 2., 281-301. http://doi.org/bp6q87 
Barabási-Albert L. (2016): Hálózatok tudománya. Libri Kiadó, Budapest

Baretta, A. (2008): The functioning of co-opetition in the health-care sector: An explorative analysis. Scandinavian Journal of Management, 3., 209-220. http://doi.org/d7hkjf

Barthélemy, M. (2011): Spatial networks. Physics Reports, 1-3., 1-101. http://doi.org/bv242z

Bengtsson, M., Kock, S. (1999): Cooperation and competition in relationships between competitors in business networks. Journal of Business and Industrial Marketing, 3., 178-194. http://doi.org/b98p4v

Bourdieu, P. (2004): Gazdasági tőke, kulturális tőke, társadalmi tőke. In: Angelusz R. (szerk.): A társadalmi rétegződés komponensei. Új Mandátum Könyvkiadó, Budapest, 122-137.

Bradenburger, A. M., Nalebuff, B. J. (1996): Co-opetition. Doubleday Currency, New York

Breuer, J. B., McDermott, J. (2012): Culture, caution, and trust. Journal of Development Economics, 1., 15-23. http://doi.org/d7b7nf

Breznitz, D. (2009): Globalization, coopetition strategy and the role of the state in the creation of new high-technology industries. In.: Dagnino, D. B., Rocco, E. (eds.): Coopetition strategy. Routledge Press, London, New York, 103-128.

Brinkhoff, T., Kresse, W. (2012): Databases. In.: Kresse, W., Danko, D. M. (eds.): Springer handbook of geographic information. Springer, Heidelberg, 61-109.

Choi, P., Garcia, R., Friedrich, C. (2010): The drivers for collective horizontal coopetition: A case study of screwcap initiatives in the international wine industry. International Journal of Strategic Business Alliances, 3., 271-290. http://doi.org/czfhhm

Corrado, L., Fingleton, B. (2012): Where is the economics in spatial econometrics? Journal of Regional Science, 2, 210-239. http://doi.org/bk6f6g

Czakon, W., Rogalski, M. (2014): Coopetition typology revisited - a behavioural approach. International Journal of Business Environment, 1., 28-46. http://doi.org/cr46

D'Alessandro, C., Léautier, F. (2016a): Spatial networks: connecting spaces through leaders. In.: D’Alessandro, C., Léautier, F. (eds.): Cities and spaces of leadership. A geographical perspective. Palgrave Macmillan, London, 126-143. http://doi.org/cr47

D’Alessandro, C., Léautier, F. (eds.) (2016b): Cities and spaces of leadership. Palgrave Macmillan, London http://doi.org/cr48

Dagnino, G. B. (2009): Coopetition strategy: a new type of interfirm dynamics for value creation. In.: Dagnino, G. B., Rocco, E. (eds.): Coopetition strategy: theory, experiments and cases. Routledge, London, 25-43.

Dubois, A. (2015): Business networks and the competitiveness of small manufacturing firms in Sweden's northern periphery. Norwegian Journal of Geography, 3., 135-151. http://doi.org/f3n399

Freeman, L. C. (1979): Centrality in social networks conceptual clarification. Social Networks, 3., 215-239. http://doi.org/bx3m36

Gnyawali, D. R., He, J., Madhavan, R. (2006): Impact of co-opetition on firm competitive behavior: An empirical examination. Journal of Management, 4., 507-530. http://doi.org/bmdr6f

Gnyawali, D. R., Madhavan, R., He, J., Bengtsson, M. (2016): The competition-cooperation paradox in inter-firm relationships: A conceptual framework. Industrial Marketing Management, 53., 7-18. http://doi.org/f3pkq4

Haggett, P., Chorley, R. J. (1969): Network analysis in geography. Edward Arnold, London

Holl, A., Mariotti, I. (2018): The geography of logistics firm location: The role of accessibility. Networks and Spatial Economics, 2., 337-361. http://doi.org/cr49

Jackson, M. (2008): Social and economic networks. Princeton University Press, Princeton

Jóna Gy. (2016): A koopetitív kkv-hálózatok területi dimenziói és hatásai. Területi Statisztika, 1., 66-88. http://doi.org/cr5b

Jóna, Gy. (2017a): Roles of the coopetitve networks in the local business life. Journal of Economics and Management, 1., 26-41. http://doi.org/cr5c

Jóna Gy. (2017b): Versenytársak együttműködésének hatása a regionális fejlődésre. Közgazdasági Szemle, január, 54-73. http://doi.org/cr5d

Kerr, A. (2017): Global games. Production, circulation and policy in the networked area. Routledge, New York

Lawson, R., Guthrie, J., Cameron, A., Fischer, W. C. (2008): Creating value through cooperation: An investigation of farmers' markets in New Zealand. British Food Journal, 1., 11-25. 
http://doi.org/cpen6f

Lengyel I. (2010): Regionális gazdaságfejlesztés. Akadémiai Kiadó, Budapest

Luo, X. (2007): A coopetition perspective of global competition. Journal of World Business, 2., 129-144. http://doi.org/cbb4g2

Lyson, T. A., Stevenson, G. W., Welsh, R. (2008): Food and the mid-level farm: Renewing an agriculture of the middle. MIT Press, Cambridge http://doi.org/cr5f

Mariani, M. M. (2016): Coordination in inter-network coopetition: Evidence from the tourism sector. Industrial Marketing Management, 53., 103-123. http://doi.org/cr5g

Ngowi, A. B., Pienaar, E. (2005): Trust factor in construction alliances. Building Research and Information, 3., 267-278. http://doi.org/cmwn2q

O'Sullivan, D. (2014): Spatial network analysis. In. Fischer, M. M., Nijkamp, P. (eds.): Handbook of regional science. Springer, Berlin, Heidelberg, 1253-1273. http://doi.org/cr5h

Osarenkhoe, A. (2010): A study of inter-firm dynamics between competition and cooperation A coopetition strategy. Journal of Database Marketing and Customer Strategy Management, 3-4., 201-221. http://doi.org/dbm38p

Pathak, S. D., Wu, Z., Johnston, D. (2014): Toward a structural view of co-opetition in supply networks. Journal of Operations Management, 5., 254-267. http://doi.org/cr5j

Petter, R. R. H., Resende, L. M., Júnior, P. P. A., Horst, D. J. (2014): Systematic review: an analysis model for measuring the coopetitive performance in horizontal cooperation networks mapping the critical success factors and their variables. The Annals of Regional Science, 1., 157-178. http://doi.org/cr5k

Quintana-García, C., Benavides-Velasco, C. A. (2004): Cooperation, competition, and innovative capability: A panel data of European dedicated biotechnology firms. Technovation, 12., 927-938. http://doi.org/d98xhp

Ritala, P. (2012): Coopetition strategy - When is it successful? Empirical evidence on innovation and market performance. British Journal of Management, 3., 307-324. http://doi.org/c3tz7m

Ritala, P., Golnam, A., Wegman, A. (2014): Coopetition-based business models: The case of Amazon.com. Industrial Marketing Management, 2., 236-249. http://doi.org/gdncgt

Rusko, R. (2011): Exploring the concept of coopetition: A typology for the strategic moves of the Finnish forest industry. Industrial Marketing Management, 2., 311-320. http://doi.org/b6cpwq

Scherngell, T. (ed.) (2013): The geography of networks and R\&D collaborations. Springer, Heidelberg http://doi.org/f3swqs

Schulze-Ehlers, B., Steffen, N., Busch, G., Spiller, A. (2014): Supply chain orientation in SMEs as an attitudinal construct: Conceptual considerations and empirical application to the dairy sector. Supply Chain Management: An International Journal, 4., 395-412. http://doi.org/f6g6bv

Vesalainen, J., Valkokari, K., Hellström, M. (eds.) (2017): Practices for network management. In search of collaborative advantage. Palgrave Macmillan, London http://doi.org/cr5m

Watts, D. J., Strogatz, S. H. (1998): Collective dynamics of 'small word' networks. Nature, 393., 440-442. http://doi.org/bwp37w 